\title{
Study of Pb Heavy Metal Pollution Level on Tannin Content of Seaweed (Kappaphycus alvarezii) in Bluto and Talango Sea Waters, Sumenep, East Java
}

\author{
Catur Pujiono $^{1}$, Akhmad Taufiq Mukti ${ }^{2 *}$ and Woro Hastuti Satyantini ${ }^{2}$ \\ ${ }^{1}$ Aquaculture Study Program, Faculty of Fisheries and Marine Sciences, Airlangga University, \\ Surabaya 60115, Indonesia \\ ${ }^{2}$ Department of Fish Health Management and Aquaculture, Faculty of Fisheries and Marine Sciences, \\ Airlangga University, Surabaya 60115, Indonesia
}

Correspondence :

akhmad-t-m@fpk.unair.ac.id

Received : 2020-01-03

Accepted : 2020-06-05

Keywords :

Seaweed, Water pollution, Heavy metal $(\mathrm{Pb})$, Tannin content

\begin{abstract}
Euchema cottoni or Kappaphycus alvarezii is one type of seaweeds that is widely cultivated in Indonesia. This study is aimed to determine the tannin levels in $K$. alvarezii and the relationship of $\mathrm{Pb}$ heavy metal pollution level with tannin levels in $K$. alvarezii in different waters. This study used an observational experiment, and samples were taken from two different locations with 4 stations in each. $K$. alvarezii was taken and was then measured for the tannin levels, water quality, and heavy metals $(\mathrm{Pb})$ in water and seaweed. The results were analyzed at PT. Sucofindo and the Laboratory of Testing Service Unit, Airlangga University Surabaya. The data were analyzed using a statistical test in the form of a t-test to determine the differences in samples in both waters, and a C-square test was used to determine the relationship between PB and tannin levels in $K$. alvarezii. The results showed that the level of $\mathrm{Pb}$ heavy metal pollution in the two waters did not show a significant difference due to water quality which was quite similar in both locations. Moreover, the tannin content in K. alvarezii in Bluto waters $(0.053 \pm$ $0.004 \%)$ was higher than that in Talango waters $(0.020 \pm 0.009 \%)$. Meanwhile, a t-test showed a significant difference in seaweed tannins in both waters. The relationship between $\mathrm{Pb}$ heavy metal pollution and tannins of seaweed in Bluto and Talango waters did not affect each other, and tannin concentration was more influenced by chemical oxygen demand (COD), the salinity, and the cultivation methods used.
\end{abstract}

\section{INTRODUCTION}

Euchema cottoni or Kappaphycus alvarezii is a type of seaweed that is widely cultivated in Indonesia (Rozaki et al., 2013). This type of seaweed spreads in several regions such as South Sulawesi, Lombok, and Madura East Java (Parengrengi and Sulaeman, 2007). One of the potential seaweed developments in Madura is located in the Sumenep region.

Sumenep region as a seaweed producing area has its productions in several sub-districts, including Bluto and Talango. Water pollution caused by the accumulation of heavy metals $(\mathrm{Pb})$ will affect seaweed to grow and develop. Seaweed will form secondary metabolites to adapt to an inappropriate condition of the environment. Seaweed rarely gets serious damage during metabolism. This fact implies that seaweed cells have several mechanisms and protective compounds (Matsukawa et al., 1997). The 
protective compounds or bioactive compounds of seaweed that are commonly found are saponins, steroids, flavonoids, and tannins (Septiana and Asnani, 2012).

Tannins are astringent substances derived from plant polyphenols that can bind, precipitate, or shrink proteins. Tannins can be found in the tissue of leaves, shoots, seeds, and roots. Arnold and Targett (2002) stated that seaweed tannins have basic chemical properties and ecological roles. The ecological role of tannins in seaweed is to bind heavy metals in the seaweed network. The high content of heavy metals absorbed in the seaweed network is proportional to the high content of seaweed tannins (Toth and Pavia, 2000). This study aims to determine the levels of tannin compounds in $K$. alvarezii and the relationship between levels of $\mathrm{Pb}$ contamination and levels of tannins in $K$. alvarezii in different waters.

\section{METHODOLOGY}

\section{Place and Time}

This research was conducted in January 2019, and the sampling was carried out in Bluto and Talango sea waters, Sumenep, Madura, East Java. Water quality analysis was carried out at PT. Sucofindo Surabaya. The analyses of the levels of tannins and $\mathrm{Pb}$ heavy metals in seaweed were carried out at the Laboratory of the Testing Service Unit of Airlangga University, Surabaya.

\section{Research Material}

The research equipment used was a cold box, while equipment for water quality analysis was a $\mathrm{pH}$ meter, a DOmeter, a Secchi disk, a thermometer, and a refractometer. Equipment for tannin content analysis is a set of UV Vis spectrophotometry, a water bath, a beaker, a porcelain cup, a measuring cup, a micropipette, an oven, a volumetric pipette, a freezer, and an analytical balance.

The materials used in this study were samples of $K$. alvarezii seaweed and seawater. Samples were obtained from Bluto and Talango sea waters, Sumenep, East Java. The materials used for tannin content analysis were gallic acid (the making of the standard curve), Folin Ciocalteu, $75 \%$ ethanol, $\mathrm{Na}_{2} \mathrm{CO}_{3}$, aliquots for tannin content testing carried out in the laboratory, distilled water to rinse seaweed samples during sampling, an ammonium test kit, an aluminum paper, plastic clips, $1 \mathrm{~kg}$ large plastic bags, and a label paper.

\section{Research Design}

This research was an observational study, a type of empirical scientific research that is based on field facts and texts through sensory perception without using any manipulation (Hasanah, 2016). Each sample from the two seaweed locations was measured for tannin content, water quality, and $\mathrm{Pb}$ heavy metals in water and $\mathrm{Pb}$ heavy metals in seaweed.

\section{Work Procedures}

\section{Determination of Sampling Locations}

The sampling locations were in Bluto and Talango sea waters, Sumenep, East Java. Sampling was carried out using a simple random sampling technique (Kerlinger, 2006). The sampling locations were taken in 4 stations in both locations, at a distance of $40,60,80$, and $100 \mathrm{~m}$ from the coastline. The sampling location points are shown in Figure 1 and Figure 2. 


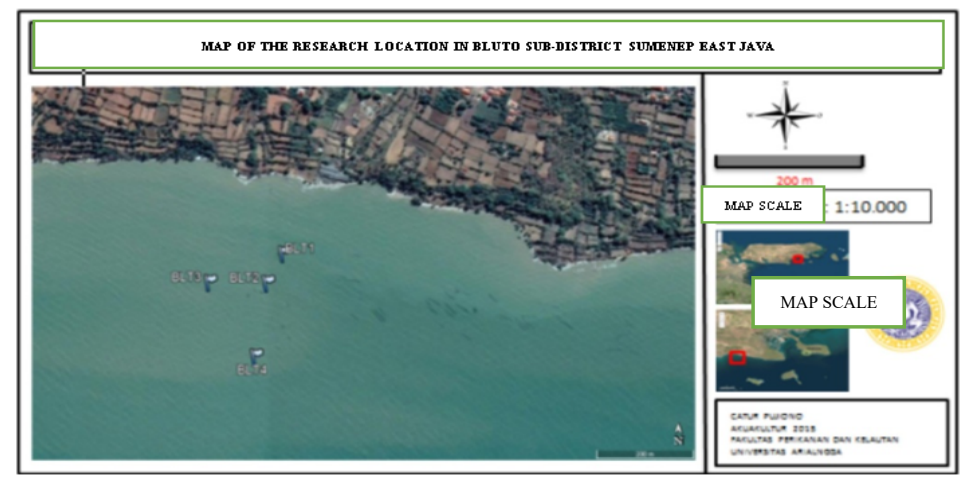

Figure 1. Map of the research location in Bluto sea waters.

Note :

Blt1 : - -7,125284 east longitude and 113,780033 south latitude (cultivation area)

Blt2 : - -7,125827 east longitude and 113,779728 south latitude (cultivation area)

Blt3 : - 7,125815 east longitude and 113,778647 south latitude (cultivation area)

Blt4 : - -7,127187 east longitude and 113,779507 south latitude (cultivation area)

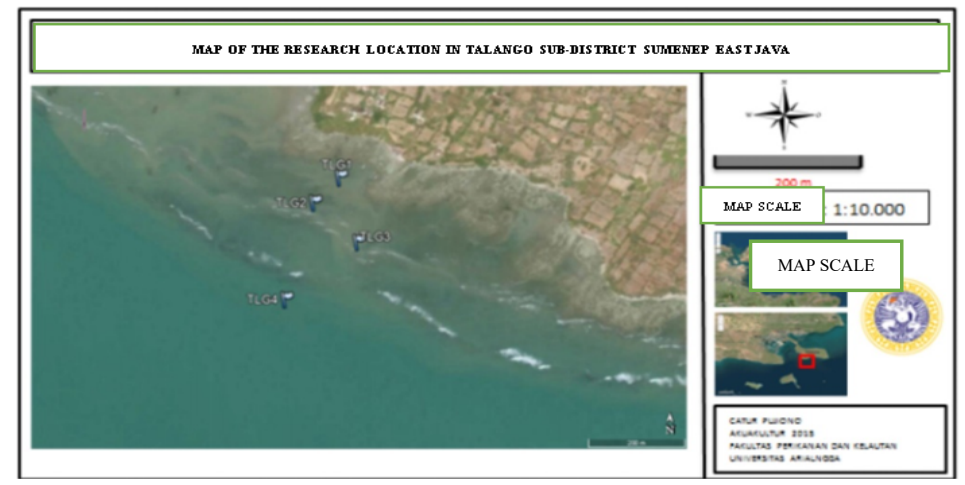

Figure 2. Map of the research location in Talango sea waters.

Note:

Tlg 1 : - -7,10281 east longitude and 113,977436 south latitude (cultivation area)

Tlg 2 : - -7,103287 east longitude and 113,976955 south latitude (cultivation area)

Tlg 3 : - 7,104032 east longitude and 113,977773 south latitude (cultivation area)

Tlg 4 : - -7,105115 east longitude and 113,97642 south latitude (cultivation area)

\section{Sampling}

Sampling was carried out directly in Bluto and Talango sea waters, Sumenep, Madura in the form of seaweed and seawater. Seawater sampling was carried out at 4 stations in each water. In-situ data collection included the measurement of water quality, namely temperature, $\mathrm{pH}$, salinity, dissolved oxygen (DO), and brightness.

The samples that had been taken were then stored in a cold box to avoid damage to the samples. After that, seawater testing was carried out, including nitrate, biological oxygen demand (BOD), chemical oxygen demand
(COD), and $\mathrm{Pb}$ heavy metals of seawater in the laboratory of PT Sucofindo Surabaya. Tannin levels and $\mathrm{Pb}$ heavy metal levels of seaweed were tested at the Laboratory of Testing Service Unit, Airlangga University, Surabaya.

\section{Method of Tanning Content Testing of Seaweed}

The measurement of the tannin content of seaweed was carried out by a spectrophotometric test. Seaweed samples were cleaned using clean water to remove dirt and salt carried from seawater, and they were heated in an oven for 4 hours at a temperature of $60^{\circ} \mathrm{C}$. Afterward, the 
seaweed was cut to a size of $2 \mathrm{~mm}$ or smaller (Deyab et al., 2016). The determination of total tannin content was carried out through a specified procedure: $50 \mathrm{mg}$ of $70 \%$ ethanol extract of the sample was dissolved with aliquots to a volume of $50 \mathrm{ml}$. The extract solution obtained was then taken in a certain amount $(5-40 \mathrm{mg} / \mathrm{l})$ and was added with $1 \mathrm{ml}$ of Folin Ciocalteu reagent, before shaken and let stand for 5 minutes. Next, the solution was added with $2 \mathrm{ml}$ of $15 \%$ $\mathrm{Na}_{2} \mathrm{CO}_{3}$ solution and was shaken until it was homogeneous and let stand for 5 minutes. Following this, the solution was added with $10 \mathrm{ml}$ of aliquots. The absorbance of the samples was observed at a wavelength of $765 \mathrm{~nm}$. The total tannin level was then calculated equivalent with the gallic acid equivalent (GAE) based on the research method of Amelia (2015).

\section{Method of $\mathrm{Pb}$ Heavy Metal Level Testing}

The analysis of $\mathrm{Pb}$ levels in seaweed and seawater was carried out using an Atomic Absorbance Spectrophotometric (AAS). AAS has a principal on the absorption of light by atoms. The atom absorbs this light at a specific wavelength, depending on the nature of the element. AAS includes the absorption of light by neutral atoms of metal elements that are still in their ground state. The light that is absorbed is usually ultraviolet light and visible light. The principle of AAS is the same as the absorption of light by molecules of compound ions in solution (Skoog et. al., 2000).

\section{Data Analysis}

The data were analyzed statistically in the form of a t-test to determine the comparison of different samples (Arif, 2016). The C-square test was performed to determine the relationship between $\mathrm{Pb}$ heavy metal and tannin content. Data analyses were performed by processing data using the SPSS ver. 21.

\section{RESULTS AND DISCUSSION}

The results of research observations included the content of $\mathrm{Pb}$ heavy metals in $K$. alvarezii seaweed and seawater, as well as the content of bioactive tannins in seaweed. These results were used to determine the comparison of the $\mathrm{Pb}$ heavy metal content and bioactive tannins in the two water locations, namely in Bluto and Talango sea waters, Sumenep, East Java. Water quality was used as supporting research which included data on BOD, COD, current, dissolved oxygen, $\mathrm{pH}$, nitrate, brightness, salinity, and temperature.

Table 1. $\quad$ Pb Heavy metal content in seawater and K. alvarezii.

\begin{tabular}{lccc}
\hline Water & Station & Pb in seawater $(\mathrm{mg} / \mathrm{l})$ & $\mathrm{Pb}$ in K. alvarezii $(\mathrm{mg} / \mathrm{l})$ \\
\hline \multirow{3}{*}{ Bluto } & 1 & 0.003 & 0.002 \\
& 2 & 0.002 & 0.002 \\
& 3 & 0.002 & 0.002 \\
\hline \multirow{3}{*}{ Talango } & 4 & 0.002 & 0.002 \\
\hline \multirow{3}{*}{ Mean \pm SD } & & $0.002 \pm 0.001$ & $0.002 \pm 0.000$ \\
& 1 & 0.003 & 0.002 \\
& 2 & 0.002 & 0.002 \\
& 3 & 0.002 & 0.002 \\
& 4 & 0.002 & 0.002 \\
\hline
\end{tabular}


Table 2. Tannin content in K. alvarezii.

\begin{tabular}{ccc}
\hline Station & Bluto (\%) & Talango (\%) \\
\hline 1 & 0.050 & 0.030 \\
2 & 0.060 & 0.020 \\
3 & 0.050 & 0.010 \\
4 & 0.050 & 0.020 \\
\hline Mean \pm SD & $0.053 \pm 0.004^{\mathrm{a}}$ & $0.020 \pm 0.009^{\mathrm{b}}$ \\
\hline
\end{tabular}

Note: A Superscript letter on the same line indicates a significant difference $(\mathrm{p}<0,05)$.

Table 3. Seawater quality in Bluto waters

\begin{tabular}{cccccccccc}
\hline Station & $\begin{array}{c}\text { BOD } \\
(\mathrm{mg} / \mathrm{l})\end{array}$ & $\begin{array}{c}\mathrm{COD} \\
(\mathrm{mg} / \mathrm{l})\end{array}$ & $\begin{array}{c}\mathrm{DO} \\
(\mathrm{mg} / \mathrm{l})\end{array}$ & $\begin{array}{c}\text { Current } \\
(\mathrm{cm} / \mathrm{s})\end{array}$ & $\begin{array}{c}\text { Nitrate } \\
(\mathrm{mg} / \mathrm{l})\end{array}$ & $\mathrm{pH}$ & $\begin{array}{c}\text { Salinity } \\
(\mathrm{ppt})\end{array}$ & $\begin{array}{c}\text { Tempera } \\
\text { ture }\left({ }^{\circ} \mathrm{C}\right)\end{array}$ & $\begin{array}{c}\text { Brightne } \\
\mathrm{ss}(\mathrm{cm})\end{array}$ \\
\hline 1 & 6,500 & 21,500 & 3,960 & 20 & 0,100 & 6,060 & 35 & 28 & 104 \\
2 & 6,000 & 19,800 & 3,700 & 20 & 0,052 & 6,060 & 35 & 29 & 111 \\
3 & 6,400 & 21,500 & 3,030 & 20 & 0,130 & 6,060 & 36 & 29 & 109 \\
4 & 6,500 & 21,500 & 3,900 & 20 & 0,059 & 6,070 & 36 & 29 & 143 \\
\hline
\end{tabular}

Table 4. Seawater quality in Talango waters

\begin{tabular}{cccccccccc}
\hline Station & $\begin{array}{c}\mathrm{BOD} \\
(\mathrm{m} / \mathrm{l})\end{array}$ & $\begin{array}{c}\mathrm{COD} \\
(\mathrm{m} / \mathrm{l})\end{array}$ & $\begin{array}{c}\mathrm{DO} \\
(\mathrm{m} / \mathrm{l})\end{array}$ & $\begin{array}{c}\text { Current } \\
(\mathrm{cm} / \mathrm{s})\end{array}$ & $\begin{array}{c}\text { Nitrate } \\
(\mathrm{m} / \mathrm{l})\end{array}$ & $\mathrm{pH}$ & $\begin{array}{c}\text { Salinity } \\
(\mathrm{ppt})\end{array}$ & $\begin{array}{c}\text { Tempera } \\
\text { ture }\left({ }^{\circ} \mathrm{C}\right)\end{array}$ & $\begin{array}{c}\text { Brightness } \\
(\mathrm{cm})\end{array}$ \\
\hline 1 & 4.700 & 14.900 & 3.900 & 30 & 0.160 & 6.070 & 34 & 28 & 105 \\
2 & 5.900 & 19.900 & 4.020 & 30 & 0.130 & 6.070 & 34 & 28 & 112 \\
3 & 4.500 & 14.900 & 4.340 & 30 & 0.140 & 6.060 & 34 & 29 & 135 \\
4 & 6.200 & 19.800 & 3.670 & 30 & 0.110 & 6.060 & 35 & 29 & 290 \\
\hline
\end{tabular}

The measurement results of $\mathrm{Pb}$ heavy metals in Bluto and Talango waters show no significant difference in the contamination of the two waters ( $\mathrm{p}>$ 0.05). This is due to factors, such as physical and chemical factors, which are relatively the same at both locations. A factor like water quality greatly affects water conditions in both locations. Water quality analysis shows that there is no significant difference between the two water locations. Meanwhile, one of the physical factors is water currents. Currents have an important role in water fluctuation. Triantoro et al. (2017) stated that the function of currents in waters includes planning for environmental impact analysis in waters. The current pattern described by BMKG mapping shows that currents in Bluto waters flow to Talango waters, located in the west of Bluto waters. High levels of $\mathrm{Pb}$ are generally found in locations closer to the coast. This is found in the measurement of $\mathrm{Pb}$ heavy metals of seawater, which shows that station 1 in the two locations has a higher value of $\mathrm{Pb}$ heavy metals, while the farthest point, namely station 4 in both locations shows a lower value of $\mathrm{Pb}$ heavy metals. This shows that the metal source is much influenced by activities on land. Siaka et al. (2016) stated that the farther the sampling location is from human activities in the waters, the smaller the value of $\mathrm{Pb}$ heavy metal content in seaweed because the closer it is to human activity, the more $\mathrm{Pb}$ will be absorbed by the seaweed.

$\mathrm{Pb}$ heavy metals that enter $K$. alvarezii are also still below the specified threshold value. BSNI (2009) stated that the maximum limit of $\mathrm{Pb}$ contamination in seaweed is $0.500 \mathrm{mg} / \mathrm{l}$. The t-test results for the $\mathrm{Pb}$ heavy metals in $K$. alvarezii in Bluto and Talango waters show that there is no significant difference in the contamination of the two waters. Setiawati (2009) stated that the absorption of $\mathrm{Pb}$ heavy metal ions by plants is caused by the high concentration of $\mathrm{Pb}$ heavy metals in the environment. Seaweed binds heavy metal ions including $\mathrm{Pb}$, by means of ion exchange. The ions in the thallus of seaweed are replaced by heavy metal ions (Siswati et al., 2005). 
Bluto waters have higher levels of tannins contained in K. alvarezii $(0.053 \pm$ $0.004 \%)$ compared to Talango waters $(0.020 \pm 0.009 \%)$. The $\mathrm{t}$-test results in both waters show that there is a significant difference between the tannins of seaweed in Bluto waters and Talango waters ( $\mathrm{p}$ $<0.05)$. Steinberg and Van Altena (1992) stated that macrophytes with tannin concentrations of $5-12 \%$ are very common in the temperate and tropical Atlantic, Northeast Pacific, and Antarctic Ocean. The Indo-Pacific tropics have low levels with a concentration of less than $2 \%$.

Bluto waters and Talango waters do not show a significant relationship between the presence of heavy metals $(\mathrm{Pb})$ and tannins in $K$. alvarezii. The results of the C-square test in Buto and Talango waters show that $\mathrm{Pb}$ heavy metals in waters and tannins in K. alvarezii do not influence each other. This is because the availability of $\mathrm{Pb}$ in the two waters is not large, so it does not show a strong influence. The difference in tannin content in the two waters is caused by factors other than the influence of heavy metals, such as water quality and the environment. Besada et al. (2009) stated that the capacity of seaweed to accumulate metals depends on various factors, and the two most relevant factors are the bioavailability of metals in the surrounding water and the absorption capacity of algae by tannins.

The COD value in Bluto waters shows a higher value compared to that in Talango waters. The presence of COD is directly proportional to the presence of tannins in $K$. alvarezii. Santino et al. (2002) stated that COD results in the biodegradability potential of aquatic microbiota. The adaptation of these organisms is for aerobic or anaerobic immobilization, and therefore tannin mineralization will also affect the concentration of these compounds in the environment. Salinity also affects the presence of tannins in these two waters. Salinity becomes a stressor for K. alvarezii when the low salinity in Talango waters is directly proportional to the tannin content in $K$. alvarezii. This is in accordance with the statement of Connan and Stengel (2011) that reduction in salinity decreases the total phenolic content, changes the phenolic composition by increasing the proportion of cell wall phenolics and increases the phenolic disposal of seaweed into the water to avoid stress due to low salinity so that the total phenolics of seaweed is reduced.

There are two cultivation techniques used in Bluto waters, namely longline and floating rafts. In January 2019, the Bluto waters used the longline technique, while the Talango waters used the floating raft technique. This is related to the growth and the level of photosynthesis optimization of seaweed. Huovinen and Gomez (2013) stated that tannin concentration is higher in sub-littoral algae correlated with high antioxidant activity and a decreasing photosynthesis activity in algae. Buatan (2010) stated that the raft method has better growth than the off-bottom and longline methods due to the currents and cleanliness level of the silt attached to the surface of the thallus along with direct sunlight leading to seaweed on the surface of the water or raft.

\section{CONCLUSION}

The tannin content in $K$. alvarezii in Bluto waters is higher than that in Talango waters. The relationship between $\mathrm{Pb}$ heavy metal contamination and tannins in $K$. alvarezii in Bluto and Talango waters is that they do not affect each other, and the concentration of tannins is more influenced by water quality, such as salinity, COD, and planting techniques used in both locations.

\section{ACKNOWLEDGMENT}

The researchers would like to thank colleagues who have helped the completion of this research.

\section{REFERENCES}

Amelia, F.R., 2015. Penentuan jenis tanin dan penetapan kadar tanin dari 
buah bungur muda secara spektrofotometri dan permanganomerti. Jurnal Ilmiah Mahasiswa Universitas Surabaya, 4(2), pp. 1-20. https://journal.ubaya.ac.id/index.p hp/jimus/article/view/2093/1646

Arif, M.A., 2016. Buku ajar rancangan percobaan. Fakultas Kedokteran Hewan, Universitas Airlangga. Surabaya. 105 p.

Arnold, T.M. and Targett, N.M., 2002. Marine tannins: the importance of a mechanistic framework for predicting ecological roles. Journal of Chemical Ecology, 28(10), pp. 1919-1934. https://doi.org/10.102 3/a:1020737609151

Besada, V., Andrade, J.M., Schultze, F. and González, J.J., 2009. Heavy metals in edible seaweeds commercialised for human consumption. Journal of Marine Systems, 75, pp. 305-313. https://doi.org/10.1016/j.jmarsys. 2008.10.010

BSNI [Badan Standarisasi Nasional Indonesia], 2009. SNI 01-73872009. Batas Maksimum Cemaran Logam Berat dalam Pangan. Jakarta. $25 \mathrm{p}$.

Buatan, M.F., 2010. Perbandingan metode budidaya lepas dasar, rakit apung dan metode tali panjang terhadap pertumbuhan rumput laut (Eucheuma cottonii). Tesis. Universitas Muhammadiyah Malang. Malang.

Connan, S. and Stengel, D.B., 2011. Impacts of ambient salinity and copper on brown algae: 2 . Interactive effects on phenolic pool and assessment of metal binding capacity of phlorotannin. Aquatic Toxicology, 104, pp. 1-13. https:// doi.org/10.1016/j.aquatox.2011.03 .016

Deyab, M., Elkatony, T. and Ward, F., 2016. Qualitative and quantitative analysis of phytochemical studies on brown seaweed, Dictyota dichotoma. International Journal of Engineering Development and Research, 4(2), pp.
674-678. https://www.ijedr.org/pa pers/IJEDR1602118.pdf

Hasanah, H., 2016. Teknik-teknik observasi: sebuah alternatif metode pengumpulan data kualitatif ilmuilmu sosial. Jurnal at-Taqaddum, 8(1), pp. 21-46. http://dx.doi.org/ 10.21580/at.v8i1.1163

Huovinen, P. and Gomez, I., 2013. Photosynthetic characteristics and UV stress tolerance of Antarctic seaweeds along the depth gradient. Polar Biology, 36, pp. 1319-1332. https://doi.org/10.1007/s00300013-1351-3

Kerlinger, F.N., 2006. Asas-asas penelitian behavioral. Edisi 3, Cetakan 7. Gadjah Mada University Press. Yogyakarta.

Matsukawa, R., Dubinsky, Z., Kishimoto, E., Masaki, K.F.Y. and Takeuchi, T., 1997. A comparison of screening methods for antioxidant activity in seaweeds. Journal of Applied Phycology, 9, pp. 29-35. https://doi. org/10.1023\%2FA\%3A1007935218 120

Parengrengi, A. and Sulaeman, 2007. Mengenal rumput laut Kappaphycus alvarezii. Jurnal Akualkultur, 2(1), pp. 142-146. http://dx.doi.org/10. 15578/ma.2.1.2007.142-146

Rozaki, A., Triajie, H., Wahyuni, E.A. and Arisandi, A., 2013. Pengaruh jarak lokasi pemeliharaan terhadap morfologi rumput laut Kappaphycus alvarezii di Desa Lobuk Kecamatan Bluto, Kabupaten Sumenep. Jurnal Kelaiutan, 6(2), pp.105-110. https: //doi.org/10.21107/jk.v6i2.783

Santino, C., Bianchini Jr., M.B.I. and Serrano, L.E.F., 2002. Aerobic and anaerobic degradation of tannic acid on water samples from Monjolinho reservoir (São Carlos, Sp, Brazil). US National Library of Medicine, 62(4A), pp. 585-590. https://doi. org/10.1590/S1519-69842002000 400004

Septiana, A. and Asnani, A., 2012. Kajian sifat fisikokimia ekstrak rumput laut coklat Sargassum duplicatum 
menggunakan berbagai pelarut dan metode ekstraksi. Agrointek, 6(1), pp. 22-28. https://doi.org/10.2110 7/agrointek.v6i1.1950

Setiawati, M.D., 2009. Uji toksisitas kadmium dan timbal pada mikroalga Chaetoceros gracilis. Skripsi. Program Studi Ilmu dan Teknologi Kelautan, Fakultas Perikanan dan Ilmu Kelautan, Institut Pertanian Bogor, Bogor. 80 p.

Siaka, I.M., Suastuti, N.G.A.M.D.A, and Mahendra, I.P.B., 2016. Distribusi logam berat $\mathrm{Pb}$ dan $\mathrm{Cu}$ pada air laut, sedimen, dan rumput laut di perairan Pantai Pandawa. Jurnal Kimia, 10(2), pp. 190-196. https:// doi.org/10.24843/JCHEM.2016.v1 0.i02.p04

Siswati, N.D., Indrawati, T. and Rahmah, M., 2005. Biosorpsi logam berat plumbum $(\mathrm{Pb})$ menggunakan biomassa Phanerochaete chrisosporium. Jurnal Ilmiah Teknik Lingkungan, 1(2), pp. 68-71. https: //core.ac.uk/download/pdf/12216 675.pdf

Skoog, D.A., West, D.M., Holler, F.J. and Crouch, S.R., 2000. Fundamentals of analytical chemistry. Brooks Cole Publisher. pp. 881-992.

Steinberg, P.D. and Van Altena, I., 1992. Tolerance of marine invertebrate herbivores to brown algal phlorotannins in temperate Australasia. Ecology Monograph, 62, pp. 189-222. https://doi.org/10. 2307/2937093

Toth, G. and Pavia, H., 2000. Lack of phlorotannin induction in the brown seaweed Ascophyllum nodosum in response to increased copper concentrations. Marine Ecology Progress Series, 192, pp. 119-126. https://doi.org/10.2307/24855716

Triantoro, D.D., Suprapto, D, and Rudiyanti, S., 2017. Kadar logam berat besi $(\mathrm{Fe})$, seng (Zn) pada sedimen dan jaringan lunak kerang hijau (Perna viridis) di perairan Tambak Lorok Semarang. Journal of Maquares, 6(3), pp. 173-180. https: //ejournal3.undip.ac.id/index.php/ maquares/article/view/20573/193 54 